\title{
MENGGAGAS SISTEM PEMILIHAN UMUM YANG SESUAI DENGAN SISTEM DEMOKRASI INDONESIA
}

\author{
Oleh \\ Budiono \\ Mahasiswa Program Doktor Ilmu Hukum Fakultas Hukum UNTAG Semarang
}

\begin{abstract}
Abstrak
Sistem pemilu di Indonesia adalah cara untuk menerapkan dan memberi kebebasan seluas luasnya pada setiap warga negara, agar memakai hak pilihnya untuk memilih wakil rakyat yang dinginkan. Pemilu dilaksanakan di Indonesia pertama kali adalah ditahun 1955. Dalam Undang undang No.27 tahun 1953 menegaskan bahwa pemilu dilakukan harus secara langsung, umum, bebas dan rahasia. Pada Pemilihan umum tahun 2009 dan Tahun 2014 digunakan sistem proporsional Perdebatan diantara elit partai politik untuk menggagas mengenai sistem pemilu legislatif untuk pemilihan legislatif pada tahun 2019 kembali muncul. Perdebatan muncul terfokus pada persoalan mempertahankan sistem pemilihan proporsional terbuka atau kembali ke proporsional tertutup. Tulisan ini akan mengkaji sistem pemilihan umum yang ideal sesuai demokrasi yang diterapkan di Indonesia.
\end{abstract}

Kata Kunci: Sistem Pemilihan Umum, sistem demokrasi Indonesia.

\section{INITIATING THE GENERAL ELECTION SYSTEM IN ACCORDANCE WITH THE INDONESIAN DEMOCRACY SYSTEM}

\author{
By \\ Budiono \\ Student of Doctoral Program of Law Faculty of Law, UNTAG Semarang
}

\begin{abstract}
General Election system in Indonesia is a way to apply and give the widest possible freedom to every citizen, in order to exercise his / her right to vote for the wanted people's representatives. The election was held in Indonesia for the first time in 1955. Under Law No.27 of 1953 confirmed that elections should be conducted directly, publicly, freely and secretly. In the 2009 and 2014 elections the proportional system of debate among the elite of political parties to initiate the legislative election system for legislative elections in 2019 re-emerged. The debate appears focused on the issue of maintaining an open proportional election system or returning to a closed proportional. This paper will examine the ideal electoral system according to the democracy applied in Indonesia.
\end{abstract}

Keywords: General Election System, Indonesian democratic system 


\section{A. LATAR BELAKANG}

Perdebatan di antara elit partai politik mengenai sistem pemilihan anggota legeslatif untukpemilihanlegeslatif tahun 2019 kembali muncul. Perdebatan yang muncul masih terfokus pada persoalan mempertahankan sistem pemilihan proporsional terbuka atau kembali ke proporsional tertutup (Pikiran Rakyat, 22 Juli 2016)

Pada Pemilihan Umum Tahun 2009 dan 2014 digunakan sistem proporsional terbuka. Namun dalam kenyataannya pelaksanaan sistem proporsional daftar terbuka ini menyisakan beberapa permasalahan.

Dalam sistem proporsional terbuka, rakyat berdaulat penuh. Namun realitas kondisi masyarakat yang masih lapar dan miskin, cenderung memilih wakil pemilik modal dan berduit dengan mengabaikan soal fatsun politik, moralitas, apalagi kapasitas. Akibatnya sistem proporsional terbuka justru melahirkan wakil rakyat karbitan yang masih belajar, belum teruji dan sebagian bukan kader terbaik partai sehingga terpilih wakil yang gagal menjaga pintu (gate keepers) moral dan tanggung jawab. Alih-alih memperjuangkan rakyat, fungsi pengawasanpun tidak maksimal. Selain itu konsekuensi proporsional terbuka adalah terjadinya persaingan yang kurang sehat (politik destruktif) antar caleg dalam satu partai, kontestasi sesama caleg internal satu partai dan bukan dengan partai lain.

Adapun kelebihan proporsional terbuka adalah siapa yang akan duduk di parlemen memang sepenuhnya bergantung pada rakyat, bukan partai. Sistem proporsional terbuka menjamin dan memastikan suara rakyat menjadi penentu siapa-siapa saja yang akan duduk di parlemen. Alokasi nilai-nilai secara otoritatif dari partai kembali nampak.

Sebaliknya sistem proporsional tertutup dianggap akan mengembalikan oligarki kepartaian dan menguatnya partai (Struggle for power). Kelemahan sistem prporsional tertutup diantaranya menutup kanal partisipasi publik yang lebih besar, menjauhkan ekses hubungan antara pemilih dan wakil rakyat sehingga seringkali pasca pemilu menjadi rentetan akumulasi kekecewaan publik. .Sistem proporsional tertutup juga membuat komunikasi politik tidak berjalan dan kesempatan calon terpilih menjadi lebih tidak adil. Tidak sampai disitu, krisis calon anggota legeslatif (caleg) tidak bisa dielakkan karena sedikit yang berminat dan serius mau jadi caleg karena sudah bisa diprediksi siapa yang akan terpilih.

Dengan demikian dalam sistem proporsional tertutup, partai berkuasa penuh, partai menjadi penentu siapa-siapa yang akan duduk di kursi parlemen setelah perolehan suara partai dikonversikan ke jumlah kursi.

Namun demikian sistem pemilu proporsional tertutup dianggap mampu meminimalisir politik uang, spektrumnya dapat menekan biaya pemilu yang cenderung mahal. Pelaksanaan sistem proporsional terbuka membuat pemilu mahal. Kelebihan proporsional tertutup adalah bahwa masyarakat cukup memilih partai dan partai yang akan mengirimkan kader-kader terbaiknya ke parlemen, sebab partai tahu betul siapa kader yang punya kapasitas, integritas dan narasi structural dan kultural.

Sementara itu Kementerian Dalam Negeri memiliki tiga opsi sistem pemilu anggota DPR dan DPRD yang dituangkan dalam draft kodifikasi RUU Pemilu. Ketiga opsi itu adalah sistem pemilu proporsional terbuka, tertutup, dan kombinasi (CNN 26 Agudtus 2016).

Pada opsi sistem proporsional terbuka, pemungutan suara dirancang berjalan sama seperti pemilu-pemilu sebelumnya. Pemegang hak suara dapat memilih partai politik dan calon anggota legeslatifnya secara bebas. Penentuan caleg yang meraih kursi di lembaga legeslatif ditentukan oleh besaran 
suara yang diperoleh saat pemungutan suara.

Sementara pada sistem proporsional tertutup pemegang hak suara hanya bisa memilih parpol. Penentuan caleg yang menenpati kursi perwakilan rakyat murni menjadi kewenangan partai dengan memperhatikan besaran jatah kursi yang mereka peroleh dalam pemilu.

Pada sistem proporsional campuran, pemegang hak suara dapat memilih parpol atau caleg yang diajukan. Namun parpol memiliki kewenangan memilih caleg yang akan ditempatkan di lembaga perwakilan tanpa haus terpaku pada perolehan suara caleg.

Dari paparan realitas yang terjadi di lapangan tersebut dapat ditarik benang merah poin penting permasalahannya adalah bagaimana memulihkan kembali degradasi otoritas kekuasaan partai dalam hal rekruitmen kepemimpinan melalui sistem pemilihan umum yang akan kita pilih sehingga nilai-nilai demokrasi tetap terjaga, tanpa dikotori oleh politik uang dan menjamurnya caleg instan menjelang pemilu yang potensial merusak kaderisasi partai politik Indonesia.

\section{B. PERMASALAHAN}

Bagaimanakah Sistem Pemilihan Umum yang Ideal sesuai Demokrasi yang diterapkan di Indonesia?

\section{PEMBAHASAN}

\section{A. Pengertian Demokrasi}

Jean Bodin sebagai Bapak Teori Kedaulatan mungkin akan terkejut mengetahui betapa jauh bergesernya apa yang dahulu ia teorikan. Awalnya, kedaulatan "hanya" diartikan sebagai "kekuasaan tertinggi terhadap para warga negara dan rakyat tanpa suatu pembatasan oleh peraturan perundang-undangan."1 Dengan kata lain, raja adalah pemilik negara.

Setelah itu munculah kedaulatan negara yang sayangnya kemudian melahirkan kekuasaan absolut para penguasanya. Meski ada pembatasan kekuasaan melalui konstitusi, pada praktiknya penguasa dengan kekuasaan absolut ini sering sama seperti raja.

Baru pada abad yang lebih modern, kedaulatan raja yang menjelma menjadi kedaulatan negara berhasil tersungkur dan memunculkan kedaulatan baru, dimana kekuasaan berada di tangan rakyat. Ajaran kedaulatan rakyat ini memberikan kekuasaan tertinggi kepada rakyat atau disebut pemerintahan dari rakyat, oleh rakyat, dan untuk rakyat. Kita kemudian menyebutnya sebagai demokrasi.

Dalam demokrasi sebagaimana JJ Rousseu pelopori, kekuasaan dilaksanakan wakil-wakil rakyat maupun oleh mereka yang dipilih langsung oleh rakyat. Untuk itu, perlu dilaksanakan pemilihan umum yang langsung, umum, bebas, serta rahasia. ${ }^{2}$

Jauh sebelum JJ Rousseu mendeklarasikan kedaulatan rakyat, adalah Yunani di masa-masa sebelum Masehi telah mengenal demokrasi. Maka, pengertian demokrasi dalam tinjauan bahasa (etimology) baik asal kata maupun asal bahasanya adalah gabungan dari dua kata dalam bahasa Yunani, yaitu "Demos" yang berarti rakyat atau penduduk suatu wilayah, dan "Cratein" atau "Cratos" yang berarti pemerintahan atau pemerintahan/ otoritas, Sehingga demokrasi sederhananya mengandung arti berarti pemerintahan rakyat atau kedaulatan/otoritas rakyat. ${ }^{3}$

\footnotetext{
1 Andi Mutari Pide, Pengantar Hukum Tata Negara, (Jakarta: Wildan Akademika dan Universitas Ekasakti Press. 2008) hlm. 16

$2 \quad$ Ibid, hlm. 17

3 Ruslan Abdulgani, Beberapa Catatan tentang Pengamalan Pancasila dengan Penekanan kepada Tinjauan Sila ke-4 yaitu Demokrasi Pancasila, dalam Demokrasi Indonesia Tinjauan Politik, Sejarah,
} 
Demokrasi dalam konsep ilmu pengetahuan modern, khususnya dalam kajian politik dan hukum ketatanegaraan pertama kali dilaksanakan di negara Athena yang berbentuk polis, dimana dalam pelaksanaan pemerintahan yang berhubungan dengan kepentingan-kepentingan umum (public), masyarakat dilibatkan dalam kebijakan pengambilan keputusan. Ciri utama pemerintahan demokrasi Athena ini adalah adanya partisifasi atau keterlibatan langsung masyarakat dalam pemerintahan, tanpa melihat apakah masyarakat yang dilibatkan tersebut mengerti atau tidak.Jadi titik sentral dari pemerintahan demokrasi saat itu adalah partisifasi masyarakat dalam bidangbidang pemerintahan sebagai dampak dari kedaulatan rakyat.

Mengingat kedaulatan itu melekat pada diri orang untuk mengatur dan mempertahankan dirinya, serta mengingat rakyat itu bukan pula satu atau dua orang, tetapi merupakan gabungan atau kumpulan dari orang-orang yang secara sadar bergabung untuk mengatur diri mereka, maka kedaulatan itu pun kemudian digabung pula. Kedaulatan rakyat ini pun bukan untuk melindungi sebagian rakyat dan menindas sebagian yang lain. Tetapi untuk melindungi keseluruhan rakyat dalam wilayah kedaulatan negara, sesuai dengan tujuan negara sebagaimana tercantum dalam konstitusi.

Ruslan Abdulgani mengutip dari buku Sejarawan Yunani Thucidides "History of the Peloponnesian War" yang juga mengutip ucapan beberapa negarawan dan ilmuwan Yunani memberikan penjelasan tentang arti materiil dari demokrasi, diantaranya: ${ }^{4}$

1. Pericles, "Our constitution is named a democracy because it is in the hands not of the few, but of the many" (Konstitusi kita

Ekonomi-Koperasi dan Kebudayaan, (Yogkarta: Widya Patria , 1995), hlm:1

$4 \quad$ Ibid, hlm. 2 dinamakan demokrasi, karena kekuasaan tidak ditangan segolongan kecil, tapi ditangan banyak rakyat).

2. Athenagores, "I say first, that the word demos, or people, include the whole state, oligarchy only a part; next, that if the best guardians of property are the richt, and the best counselors the wise, none can hear and decide so well as the many; and that all these talents, severally and collectively, have their just place in a democracy" (Bagi saya, pertama, kata demos atau rakyat mencakup seluruh negara, oligarki hanya sebagian. Kedua, apabila orang-orang kaya adalah penjaga yang terbaik bagi harta milik, dan orang-orang arif pandai adalah penasehat-penasehat terbaik, tapi tidak ada yang mengalahkan orang banyak dalam kearifan mendengar dan memutuskan. Semua kepandaian, bakat, dan akal budi itu, secara sendiri-sendiri dan kolektif, mempunyai tempat yang adil wajar dalam demokrasi)

3. Herts dalam bukunya Political Realism and Political Idealism sebagaimana dikutip oleh Sukarna dalam buku Sistem Politik, menyebutkan bahwa "Democracy is a form of government in which no one member, has political prerogative over any other. Government thus the rule of all overall in the common, as opposed to the individual or separate group interest), ${ }^{5}$ yang berarti bahwa "Demokrasi adalah bentuk pemerintahan dimana tidak satu orangpun anggota (rakyat/kelompoknya), mempunyai hak prerogatif politik terhadap anggota (rakyat/ kelompoknya) lainnya.Pemerintahan adalah dilakukan dengan aturan oleh keseluruhan anggota (rakyat/kelompoknya) untuk keseluruhan masyarakat, sebagai suatu penentangan terhadap kepentingan perseorangan atau kelompok terpisah.

Josefh A. Schmeter menyebutkan, "demokrasi merupakan suatu perencanaan

5 Sukarna, Sistem Politik, (Bandung: PT Citra Aditya Bakti, 1990), hlm: 37 
institusional untuk mencapai suatu keputusan politik dimana individuindividu memperoleh kekuasaan untuk menentukan dan memutuskan dengan cara perjuangan kompetitif atas suara rakyat", sedangkan Sidney Hook, menyebutkan "demokrasi sebagai bentuk pemerintahan dimana keputusan-keputusan pemerintah yang penting secara langsung atau tidak langsung didasarkan pada kesepakatan mayoritas yang diberikan secara bebas dari rakyat dewasa", adapun Philippe C.Schmiiter dan Terry Lynn Karl menyebutkan bahwa "demokrasi merupakan suatu sistem pemerintahan dimana pemerintah dimintai pertanggungjawaban atas tindakan-tindakan mereka di wilayah publik oleh warga negara, yang bertindak secara tidak langsung melalui kompetisi dan kerjasama para wakil mereka yang telah terpilih" 6

Dari pendapat para ahli di atas terdapat benang merah atau titik singgung tentang pengertian demokrasi, yaitu rakyat sebagai pemegang kekuasaan, pembuat dan penentu keputusan dan kebijaksanaan tertinggi dalam penyelenggaran negara dan pemerintahan serta pengontrol terhadap pelaksanaan kebijakannya baik yang dilaksanakan secara langsung oleh rakyat atau mewakilimya melalui lembaga perwakilan. Karena itu negara yang menganut sistem demokrasi diselengarakan berdasarkan kehendak dan kemauan rakyat mayoritas serta tidak mengesampingkan rakyat minoritas.

Moh. Mahfud MD menyatakan bahwa negara yang menganut asas demokrasi, maka kekuasaan pemerintah berada di tangan rakyat. Pada negara yang menganut asas demokrasi ini didalamnya mengandung unsur; pemerintahan dari rakyat (government of the people), pemerintahan oleh rakyat

$6 \quad$ U. Ubaidillah, , Pendidikan Kewarganegaraan: Demokrasi, HAM dan Masyarakat Madani, (Jakarta: IAIN Jakarta Press, 2000), hlm: 162 (government by the people), dan pemerintahan untuk rakyat (government for the people). ${ }^{7}$

\section{B. Pengertian Pemilu}

Pemilihan umum adalah merupakan institusi pokok pemerintahan perwakilan yang demokratis, karena dalam suatu negara demokrasi, wewenang pemerintah hanya diperoleh atas persetujuan dari mereka yang diperintah. Mekanisme utama untuk mengimplementasikan persetujuan tersebut menjadi wewenang pemerintah adalah melalui pelaksanaan pemilihan umum yang bebas, jujur dan adil, khususnya untuk memilih presiden / kepala daerah. Bahkan dinegara yang tidak menjunjung tinggi demokrasi sekalipun, pemilihan umum diadakan untuk memberi corak legitimasi kekuasaan (otoritas). ${ }^{8}$

Oleh karena itu, pemilihan umum yang dituntut demokrasi bukanlah sembarang pemilihan umum, akan tetapi pemilihan umum dengan syarat-syarat tertentu. Pemilihan umum yang tidak memenuhi syarat-syarat tersebut hanyalah merupakan simbol belaka yang tidak banyak artinya bagi perkembangan demokrasi. Meskipun ketentuan perundang-undangan yang ada memang sudah memberikan syaratsyarat tersebut, sebagaimana misalnya istilah langsung, umum, bebas, rahasia yang bila dilaksanakan sesuai arti yang terkandung didalamnya sudah menjamin terselenggaranya pemilihan umum yang demokratis, akan tetapi yang diperlukan adalah meningkatkan kualitas pemilihan umum dari pemilihan umum ke pemilihan umum, sehingga pemilihan umum yang diadakan semakin lama semakin baik.

\footnotetext{
7 Moh Mahfud MD, Hukum dan Pilar-pilar Demokrasi, (Yogyakarta: Gama Media,1999), hlm: 8

8 Marzuki, Pengaruh Sistem Pemilihan Umum Terhadap Keterwakilan Politik Masyarakat Pada DPRD-DPRD Di Provinsi Sumatera Utara, Studi Konstitusional Peran DPRD Pada Era Reformasi Pasca Pemilu 1999, Disertasi, (Medan: Program Pasca Sarjana USU, 2007), hlm. 143.
} 
Dengan demikian, pemilihan umum yang demokratis haruslah diselenggarakan dalam suasana keterbukaan, adanya kebebasan berpendapat dan berserikat, atau dengan perkataan lain pemilihan umum yang demokratis harus memenuhi unsur-unsur sebagai berikut:

1. Sebagai aktualiasi dari prinsip keterwakilan politik.

2. Aturan permainan yang fair.

3. Dihargainya nilai-nilai kebebasan.

4. Diselenggarakan oleh lembaga yang netral atau mencerminkan berbagai kekuatan politik secara proporsional.

5. Tiadanya intimidasi.

6. Adanya kesadaran rakyat tentang hak politiknya dalam pemilihan umum.

7. Mekanisme pelaporan hasilnya dapat dipertanggungkawabkan secara moral dan hukum. ${ }^{9}$

Dalam hubungan yang demikian, maka pemilihan umum sangat erat kaitannya dengan sistem pemilihan umum (electoral system). Akan tetapi, berkaitan dengan electoral system tersebut harus dibedakan antara electoral laws dengan electoral process. Didalam ilmu kepemiluan yang disebut dengan electoral laws adalah proses pembentukan pemerintahan melalui pilihan sistem pemilihan umum yang diartikulasikan kedalam suara, dan kemudian suara tersebut diterjemahkan kedalam pembagian kewenangan pemerintahan diantara partai politik yang bersaing. ${ }^{10}$

Berdasarkan pandangan yang demikian, electoral laws berkenaan dengan sistem pemilihan dan aturan yang menata jalannya pemilihan umum serta distribusi hasil

9 Rusli M. Karim, Pemilu Demokratis Kompetitif, (Yogyakarta: PT Tiara Wacana Yogya, 1991), hlm. 37

10 Dahlan Thaib dan Ni'matul Huda, Pemilu dan Lembaga Perwakilan Dalam Ketatanegaraan Indonesia, (Yogyakarta: Jurusan Hukum Tata Negara Fakultas Hukum Universitas Islam Indonesia, 1992), hlm. 31. pemilihan umum. Dalam kaitan ini sistem pemilihan umum adalah rangkaian aturan yang menurutnya pemilih mengekspresikan prefensi politik mereka, dan suara pemilih diterjemahkan menjadi kursi. Defenisi ini mengisyaratkan bahwa sistem pemilihan umum mengandung elemen-elemen struktur kertas suara dan cara pemberian suara, besar distrik serta penerjemahan suara menjadi kursi. Dengan demikian hal-hal seperti administrasi pemilihan umum dan hak pilih, walaupun penting berada diluar lingkup pembahasan sistem pemilihan umum. ${ }^{11}$

Sedangkan electoral process adalah menyangkut mekanisme yang dijalankan didalam mengelola pemilihan umum, mulai dari pendaftaran pemilih, pencalonan, kampanye (baik yang menyangkut isi, tema, prosedur, dan teknik) pemberian suara, serta penghitungan suara. ${ }^{12}$

\section{Sistem Pemilu}

Polarisasi partai politik sedikit banyak juga dipengaruhi oleh sistem pemilunya, adaduasistempemilihanumum, yaitu: perwakilandistrik/mayoritas (single memberconstituency) dan sistemperwakilan berimbang(proportionalrepresentation) ${ }^{13}$.

\section{1) SistemDistrik}

Sistim ini merupakan sistim pemilihan yang paling tua dan didasarkan atas kesatuan geografis.Setiap kesatuan geografis yang dinamakan sebagai distrik memperoleh satu kursi di parlemen. Negara diabagi kedalam wilayah/distrik yang sama jumlah penduduknya. Dalam sistem ini, calon yang mendapatkan suara terbanyak yang akan menjadi pemenang, meskipun selisih dengan calon lain hanya sedikit. Suara yang

\footnotetext{
11 Dahlan Thaib dan Ni'matul Huda, Op.cit, hlm. 31

12 Abdul Bari Azed, Sistem-Sistem Pemilihan Umum, Suatu Himpunan Pemikiran, (Jakarta: Fakultas Hukum Universitas Indonesia, 2000), hlm. 72.

13 Jimly Asshiddiqie, Pengantar Ilmu Hukum Tata Negara, jilid II, (Jakarta: Sekretarian Jenderal dan Kepanitiaan MK RI, 2006 ) hlm. 182
} 
pendukung calon lain akan dianggap hilang dan tidak dapat membantu partainya untuk mendapatkan jumlah suara partainya di distrik lain ${ }^{14}$.

Beberapa keunggulan dari sistim $\operatorname{distrik}^{15}$ :

a. Sistim ini lebih mendorong ke arah integrasi parpol karena kursi yang diperebutkan dalam setiap distrik pemilihan hanya satu. Hal ini akan dapat mendorong parpol menyisihkan perbedaan yang ada dan mengadakan kerjasama.

b. Fragmentasi partai dan kecenderungan partai baru dapat dibendung dan akan mendorong ke arah penyederhanaan partai tanpa ada paksaan. Di Amerika dan Inggris sistem ini telah menunjang bertahanya sistemdwi partai.

c. Karena kecilnya distrik, wakil yang dipilih dapat dikenal oleh komunitasnya sehingga hubunganya dengan konstituen lebih erat dan orang yang tekah terpilih akan cenderung memperjuangkan kepentingan distriknya.

d. Bagi partai besar, sistem ini menguntungkan karena melalui distortion effect dapat meraih suara dari pemilih-pemilih lain, sehingga memperoleh dukungan mayoritas. Sehingga partai pemenang dapat mengendalikan parlemen

e. Lebih mudah bagi partai pemenang untuk menguasai parlemen sehingga tidak perlu mengadakan koalisi

Sistem distrik memang akan mengarahkan penyederhanaan partai secara alami, namun sistem ini juga tidak luput dari kelemahan, diantaranya sebagai berikut:

a. Kurang memperhatkan kepentingan

14 Miriam Budiardjo, Dasar-Dasar Ilmu Politik, edis revisi, cet ke 6, (Jakarta: Gramedia, 2013), hlm. 462 15 Ibid., hlm. 466-467 partai kecil dan golongan minoritas

b. Kurang representatif, karena partai yang calonnya kalah dalam suatu distrik akan kehilangan suarau yang telah mendukungnya

c. Sistem distrik kurang efektif dalam masyarakat yang plural karena terbagi dalam berbagai kelompok dan suku.

2) SistemProporsional

Dalam sistim ini, presentase kursi di lembaga perwakilan rakyat dibagikan kepada tiap-tiap parpol sesuai dengan presentase jumlah suara yang diperoleh tiap-tiap parpol. Jimly Asshidiqie mencontohkan model dari sistim ini, misalkan jumlah pemilih yang sah dalam pemilu 1 juta orang sedangkan jumlah kursi di perwakilan rakyat 100 kursi, maka untuk satu orang wakil rakyat membutuhkan 10 ribu suara ${ }^{16}$. Pembagian kursi di parlemen tergantung seberapa suara yang diperoleh setiap parpol.

Kelebihan/keuntungan sistem proporsional:

a. Sistem proporsional dianggap representatif karena jumlah kursi partai dalam parlemen sesuai dengn jumlah suara masyarakat yang diperoleh dalam pemilu

b. Sistem ini dianggap lebih demokratis karena tidak ada distorsi (kesenjangan antara suara nasional dan jumlah kursi dalam parlemen tanpa adanya suara yang hilang). Semua golongan dalam masyarakat memperoleh peluang untuk menampilkan wakilnya dalam parlemen

Kelemahan/kerugians

Sistem proporsional:

a. Kurang mendorong partai untuk berintegrasi atau bekerja sama satu sama lain dan memanfaatkan persamaan-

16 Jimly Asshiddiqie, op.cit., hlm. 183 
persamaan yang ada, tapai cenderung mempertjam perbedaan-perbedaan. Sehingga berakibat pada bertembahnya jumlah partai

b. Memberikan kedudukan yang kuat pada pimpinan partai menentukan daftar calon $^{17}$.

c. Oleh karena banyaknya partai yang bersaing, maka akan menyulitkan suatau partai untuk meraih suara mayoritas $(50 \% \text { lebih })^{18}$

Sistim proporsional ada dua, yaitu sistim daftar tertutup dan daftar terbuka. Dalam sistim daftar tertutup, para pemilih harus memilih partai politik dan bukan calon legislatifnya.Sedangkan dalam sistim daftar terbuka, selain memilih gambar parpol para pemilih juga memilih gambar kandidat yang diusung oleh parpol tersebut ${ }^{19}$.

3) Gabungan sistem distrik dan sistem proporsional

Karena dari kedua sistem di atas mempunyai kelebihan dan kekuarangan masing-masing, maka beberapa negara mencoba untuk menggabungkan kedua sistem tersebut.Jerman adalah salah satu contoh negara yang berhasil menerapkan gabungan kedua sistem ini, di Jerman setengah dari parlemen dipilih dengan sistem distrik dan setengahnya lagi dengan sistem proporsional.Setiap pemilih mempunyai dua suara; pemilih memilih calon atas dasar sistem distrik (sebagai suara pertama) dan pemilih juga memilih partai dengan dasar sistem proporsional (sebagai suara kedua).Di Jerman juga diterapkan model parliamentary threshold sebagaimana yang kita kenal

17 Hal ini berlaku jika menggunakan sistem nomor urut, sehingga yang diuntungkan adalah nomor urut yang pertama.Tetapi yang terjadi di Indonesia sekarang menggunakan sistem terbukan dengan suara terbanyak, sehingga hal ini tidak terlalu berpengaruh.

Miriam Budiardjo, op. cit., hlm. 469

19 Novi Hendra, Sistem Pemilihan Umum, http://www. slideshare.net/Hennov/sistem-pemilihan-umum, akses tanggal 19 Februari 2013 sekarang. Di sana, sebuah partai akan mempunyai kursi di parlemen jika meraih minimal $5 \%$ dari jumlah suara sah secara nasional atau memenagnkan setidaknya $3 \%$ distrik pemilihan ${ }^{20}$.

\section{Perjalanan Sistem Pemilu di Indonesia}

Sejak dulu sampai sekarang Indonesia tidak pernah berhenti mencari sistem pemilu yang benar-benar cocok.Namun yang pasti, sejak dahulu sampai sekarang Indonesia selalu menerapkan model proporsional meskipun belakangan ini model proporsional yang berlaku bukan semurni asalnya. Pada tahun 1955 pemilu diadakan dua kali; memilih anggota DPR pada bulan September dan memlih anggota Konstituante pada bulan Desember dengan model proporsional karena pada waktu itu hanya sistem proporsional yang dikenal di Indonesia. Pemilu tersebut menghasilkan 27 partai dan satu perorangan, partai yang sangat menonjol adalah Masyumi, PNI, NU dan PKI ${ }^{21}$.

Pada tahun 1966 dan 1967 sistem distrik sudah mulai didiskusikan, pada saat itu, sistem distrik dirasa dapat mengurangi jumlah partai secara alamiah. Namun hasil tersebut ditolak ketika pada tahun 1967 DPR membahas RUU yang terkait dengannya. Sehingga pemilu tahun 1971 masih tetap menggunakan sistem proporsional dengan beberapa modifikasi.Pertama, setiap daerah tingkat II/Kabupaten dijamin mendapatkan satu kursi di DPR. Kedua, dari 460 anggota DPR, 100 diangakat; 75 dari ABRI dan 25 dari Non-ABRI yang diangkat dari utusan golongan dan daerah. Pada tahun 1971, pemilu diikuti oleh 10 partai politik ${ }^{22}$.

Pada tahun 1973 Soeharto menyuruh agar partai yang ada melakukan fusi, sehingga pada pamilu tahun 1977 anggota pemilu hanya tiga partai, yakni Golkar, PPP

Miriam Budiardjo, op.cit., hlm. 472

Ibid., hlm. 474

Ibid., hlm. 475 
dan PDIP. Setelah reformasi bergulir, ada sedikit perbedaan dalam susunan parlemen dan model pemilihanya.DPD dipilih dengan model distrik, sedangkan DPR dan DPRD masih menggunakan sistem proporsional daftar terbuka. Pada pemilu 2004, ada unsur distrik dalam model proprsionalnya, yakni suara perolehan suatu partai sisebuah Dapil yang tidak cukup untuk satu bilangan pembagi pemilih (BPP) tidak bisa ditambahkan ke perolehan partai di Dapil lain ${ }^{23}$.

\section{E. Mencari Sistem Pemilu Yang Terbaik}

Pada pemilu 1999 Indonesia menggunakan sistim proporsional tertutup, tahun 2004 menggunakan sistim proporsional semi terbuka. Dinamakan dengan semi terbuka karena penentuan siapa yang akan mewakili partai dalam perolehan kursi di parlemen tidak didasarkan pada perolehan suara terbanyak melainkan tetap berdasarkan nomor urut ${ }^{24}$. Tahun 2009 menjadi proporsional daftar terbuka setelah MK mengabulkan judicial review dengan menghapuskan pasal 214 UU No 10 th 2008 yang mengatur penetapan caleg berdasarkan nomor urut jika tidak memenuhi ketentuan $30 \%$ dari BPP. Pada tahun 2009 calon dipilih sesuai dengan suara terbanyak sehingga proporsional daftar terbuka benarbenar diterapkan.Sistim proporsional daftar terbuka dapat juga dikatakan sebagai sistim semi distrik, sebab sistim ini mengkombinasikan ciri-ciri atau lebih tepatnya kelebihan-kelebihan yang terdapat dalam sistem distrik dan proporsional, sekaligus menimalisir kekurangan yang ada pada keduanya ${ }^{25}$.

\footnotetext{
Ibid., hlm. 488

Wirat Sasongko, Sistem Pemilihan Umum di Indonesia, http://suci.blog.fisip.uns.ac.id/2012/04/20/32/, akses tanggal 1 Juli 2015

25 Hanta Yuda AR, Presidensialisme Setengah Hati, (Jakarta: Gramedia Pustaka Utama, 2010), hlm. 107
}

Pada pemilu 2004, 2009, dan 2014, sisa suara yang terdapat dalam suatu dapil tidak bisa ditambahkan ke dapil lain. Sisa kursi akan diberikan kepada sisa suara terbanyak namun tidak mencapai BPP. Sebagai contoh, partai A mendapatkan suara 150.000 sedangkan BPPnya 10.000, maka partai tersebut akan mendapatkan 10 kursi. Sedangkan sisa 5000 kursinya tidak bisa ditambahkan ke dapil lain. Jika dalam dapil tersebut sisa suara dari berbagai partai yang paling banyak adalah 5000 suara, maka sisa kursinya diserahkan kepada partai $\mathrm{A}$.

Mengenai pengaruh dari sistim pemilu dan keberadaan partai, Maurice Duverger berpendapat bahwa sistim distrik cenderung mendorong terbentuknya dua partai, sedangkan sistim proporsional cenderung mendorong terbentuknya sistim multi partai. Sistim proporsional cenderung memperbesar fraksionalisme dan mendorong terbentuknya partai-partai kecil, sehingga ia berkeyakinan kalau sistim proporsional kondusif bagi bekembangnya multi partai ${ }^{26}$.

Untuk mengurangi banyaknya partai yang tumbuh dalam sistem proporsional, Indonesia menerapkan electoral threshold dan parliamentary threshold. Pada pemilu tahun 1999 Indonesia menggunakan electoral threshold sebagaimana yang terdapat dalam pasal 39 UU No 3 tahun 1999 yang menegaskan bahwa partai politik harus memiliki 2\% dari kursi DPR atau 3\% kursi DPRD I atau II sekurang-kurangnya di setengah jumlah propinsi dan kabupaten seluruh Indonesia. Batas electoral threshold dalam pemilu 2004 naik lagi menjadi 3\% dari kursi DPR dan 4\% kursi DPRD yang tersebar di setengah jumlah provinsi atau kabupaten di Indonesia ${ }^{27}$.

Mengenai pembatasan partai politik, dalam UU pemilu 2009 yakni UU No 10 tahun

\footnotetext{
26 Ibid. hlm. 106

27 Pasal 9 UU No 12 th 2003 tentang Pemilu Anggota DPR,
} DPD dan DPRD 
2008, ketentuan parliamentary threshold mulai diberlakukan yang diatur dalam pasal 202. Dengan mulai digunakannya parliamentary threshold, maka ketentuan electoral threshold mulai dihilangkan.

Pemilu tahun 2014 diatur dengan UU No 8 tahun 2012. Dalam UU teresebut, besaran PT yang pada 2009 sebesar $2.5 \%$ dinaikkan menjadi $3.5 \%$, hal ini diharapkan dapat membuat parlemen lebih ramping. Sebagaimana yang ada, partai yang berhasil lolos menjadi peserta pemilu tingkat pusat hanya 12. Yang membedakan pemilu 2014 dan pemilu sebelumnya adalah adanya verifikasi yang ketat bagi semua parpol, baik yang sudah ada di parlemen maupun parpol baru. Pada mulanya ambang batas parliamentary threshold sekaligus akan dijadikan electoral threshold, namun setelah MK mengeluarkan putusan No.52/PUU-X/2012 semua parpol mengkuti tahapan-tahapan verifikasi. Putusan tersebut menguatkan perspektif dalam proses penyederhanaan partai, yakni dengan menghapuskan ketentuan electoral threshold dan diganti dengan parliamentary threshold sekaligus tahapan-tahapan verfikasi bagi semua parpol. Terkait hal ini, Saldi Isra Pernah menuliskannya dalam sebuah opini di harian Kompas ${ }^{28}$

"secara jujur harus diakui, sepanjang pelaksanaan pemilu setelah reformasi, verifikasi faktual untuk keseluruhan parpol calon peserta pemilu baru kali ini dilaksanakan. Misalnya, pada pemilu 2004, parpol peserta pemilu 1999 yang memperoleh 2 persen atau lebih jumlah kursi DPR atau paling kurang 3 persen jumlah kursi DPRD ditetapkan sebagai peserta pemilu tanpa verifikasi. Sementara parpol yang bergabung dengan sesama yang tak memenuhi ambang batas diverifikasi terbatas. Verifikasi lebih ketat hanya ditujukan kepada parpol baru. Dalam pemilu 2009, parpol peserta pemiluu

28 Saldi Isra, "Sembilan Tambah Satu”, Kompas, 15 januari 2013,
2004 yang memperoleh minimal 3 persen kursi DPR atau paling kurang 4 persen kursi DPRD secara otomatis menjadi peserta pemilu."

Sistemproporsional daftar terbuka dengan suara terbanyak, peningkatan parliamentary threshold dan semakin ketatnya persyaratan bagi partai untuk mengikuti pemilihan umum memang dirasakan lebih demokratis dibandingkan menggunakan sistemlainnya yang telah digunakan di Indonesia.

Meski saat ini banyak yang menginginkan sistem pemilu Indonesia kembali ke sistem proporsional tertutup namun mengingat pengalaman masa lalu, maka proporsional daftar terbuka masih layak dipertahankan. Sebagai pengingat, kuatnya pengaruh partai politik dalam menentukan wakil rakyat sebagaimana yang ada dalam sistem proporsional tertutup adalah alasan Indonesia beralih ke sistem yang sekarang. Mungkin sistem yang digunakan sekarang masih ada kekurangan, namun setidaknya sistem ini lebih mengakomodir suara rakyat dibanding sistem lainnya.

\section{A. Kesimpulan}

Implemestasi kedaulatan rakyat di Indonesia sebagaimana diamanatkan oleh Undang-Undang Dasar 1945 dilaksanakan oleh lembaga-lembaga yang dibentuk dan diisi oleh wakil-wakil rakyat atau atas pilihan wakil rakyat. Dengan kata lain, kedaulatan rakyat di Indonesia dilaksanakan oleh orangorang yang benar-benar mengikutsertakan peran rakyat dalam pengisian posisinya. Hal ini sesuai dengan doktrin dari rakyat, oleh rakyat, dan untuk rakyat sebagaimana digaungkan oleh pelopor kedaulatan rakyat.

$$
\text { Karena dalam pelaksanaan }
$$
pemerintahan rakyat diwakili oleh lembagalembaga sebagaimana tercantum dalam Undang-Undang Dasar 1945, dengan demikian jelas bahwa demokrasi tidak langsunglah yang diterapkan bangsa 
Indonesia. Hal ini lebih sesuai dengan karakteristik bangsa Indonesia yang memiliki demografi majemuk dan wilayah kekuasaan yang luas. Demokrasi tak langsung sendiri berarti bahwa seluruh rakyat memilih perwakilan mereka melalui pemilihan umum (pemilu) untuk menyampaikan pendapat dan sebagai pengambilkeputusan bagi mereka.Demokrasi tak langsung intinya semua rakyatnya memiliki hak dan daulat, namun kedaulatannya tersebut diwakilkan melalui perwakilan sehingga disebut dengan demokrasi tak langsung (perwakilan).

Agar bisa memilih wakil untuk menjalankan pemerintahan, maka diperlukan sebuah mekanisme yang menjamin aspirasi masyarakat tanpa kecuali. Mekanisme yang diamanatkan oleh Undang-Undang Dasar 1945 untuk menjamin hal tersebut adalah pemilihan umum. Sejak diadakanya pemilihan umum, Indonesia masih tetap menggunakan sistem proporsional dengan berbagai tambahan warna distrik. Kini, Indonesia memilih sistem proporsional daftar terbuka dengan suara terbanyak senbagai sistem pemilihan umum. Selain itu, digunakan jugaparliamentary thresholdyang kian meningkat setiap tahun dan semakin ketatnya persyaratan bagi partai untuk mengikuti pemilihan umum. Hal tersebut semata semata demi menjaga marwah demokrasibagi Indonesia.

\section{B. Saran}

Bangsa Indonesia harus tetap menjalankan sistem demokrasi sebagaimana yang diamanatkan dalam Undang-Undang Dasar Negara Republik Indonesia tahun 1945. Hal ini wajib dilakukan demi tetap tegaknya bangsa ini dalam menjalankan sistem demokrasi.

Meskibanyak pihak yang menggaungkan untuk kembali pada sistem pemilihan umum proporsional daftar tertutup, namun sejatinya sistem proporsional daftar terbuka memiliki keunggulan dari sisi terpenuhinya hak rakyat. Memang saat ini sistem pemilu di Indonesia masih banyak kekurangan, namun bukan berarti harus menggantinya.

Justru yang harus dilakukan adalah memperkuat sistem peraturan yang mengiringi sistem pemilu ini agar pesta demokrasi di Indonesia kian bersih dari praktek-praktek pelanggaran yang selama ini dianggap biasa terjadi. Bangsa Indonesia juga harus mau terus menggali dan mencari hal-hal terkait demokrasi demi menyempurnakan sistem yang ada sehingga bisa benar-benar sesuai dengan kepribadian dan sesuai dengan tujuan bangsa Indonesia.

\section{DAFTAR PUSTAKA}

\section{A. Buku dan Artikel}

Abdulgani,Ruslan,Beberapa Catatan tentang Pengamalan Pancasila dengan Penekanan kepada Tinjauan Sila ke-4 yaitu Demokrasi Pancasila, dalam Demokrasi Indonesia Tinjauan Politik, Sejarah, Ekonomi-Koperasi dan Kebudayaan, Yogkarta: Widya Patria. 1995.

Asshiddiqie, Jimly, Pengantar Ilmu Hukum Tata Negara, jilid II, Jakarta: Sekretarian Jenderal dan Kepanitiaan MK RI, 2006

Asshiddiqie, Jimly, Pengantar Ilmu Hukum Tata Negara, jilid II, Jakarta: Sekretarian Jenderal dan Kepanitiaan MK RI, 2006

Asshiddiqie, Jimly, Perkembangan dan Konsolidasi Lembaga Negara Pasca Reformasi, Jakarta: Sinar Grafika, tahun.

Azed, Abdul Bari, Sistem-Sistem Pemilihan Umum, Suatu Himpunan Pemikiran, Jakarta: Fakultas Hukum Universitas 
Indonesia. 2000.

Isra, Saldi, Sembilan Tambah Satu, Kompas, 15 januari 2013.

MD, Mahfud, Hukum dan Pilarpilar Demokrasi, Yogyakarta: GamaMedia.1999.

Mainwaring, Scott, Presidentialism, Multiparty Sistems and Democracy: The Difficult Equation, Working Paper \#144-September 1990.

Marzuki, Pengaruh Sistem Pemilihan Umum Terhadap Keterwakilan Politik Masyarakat Pada DPRD-DPRD Di Provinsi Sumatera Utara, Studi Konstitusional Peran DPRD Pada Era Reformasi Pasca Pemilu 1999, Disertasi, Medan: Program Pasca Sarjana USU.2007.

Pide, Andi Mutari, Pengantar Hukum Tata Negara, Jakarta: Wildan Akademika dan Universitas Ekasakti Press. 2008.

Sukarna, Sistem Politik, Bandung: PT Citra Aditya Bakti.1990.

U. Ubaidillah, Pendidikan Kewarganegaraan: Demokrasi, HAM dan Masyarakat Madani, Jakarta: IAIN Jakarta Press.2000.

Yuda AR, Hanta, Presidensialisme Setengah Hati, Jakarta: Gramedia Pustaka Utama, 2010

\section{B. Peraturan Perundang-Undangan dan Putusan}

Undang-Undang Dasar Republik Indonesia 1945

UU No. 3 tahun 1999 tentang Pemilihan Umum

UU No. 12 tahun 2003 tentang Pemilihan
Umum Anggota DPR, DPD dan DPRD

UU No. 10 tahun 2008 tentang Pemilihan Umum Anggota DPR, DPD dan DPRD

UU No. 8 tahun 2012 tentang Pemilihan Umum Anggota DPR, DPD dan DPRD

Putusan Mahkamah Konstitusi No.52/ PUU-X/2012 tentang Pengujian UndangUndang No. 8 tahun 2012 tentang Pemilihan Umum Anggota DPR, DPD dan DPRD

\section{Internet}

Hendra,Novi, Sistem Pemilihan

Umum,http://www.slideshare.net/Hennov/

sistem-pemilihan-umum, akses tanggal 1

Juli 2015

Sasongko, Wirat, Sistem Pemilihan Umum

di Indonesia, http://suci.blog.fisip.uns. ac.id/2012/04/20/32/ akses tanggal 1 Juli 2015 